Krystyna Krawiec-Złotkowska

\title{
Znaczenie konfesji katolickiej w utrzymaniu polskości na Kaszubach na przełomie XIX i XX wieku
}

\begin{abstract}
W studium zostały omówione zagadnienia dotyczące granic historycznych Kaszub i związków ich mieszkańców z Kościołem katolickim. Autorka podjęła próbę ustalenia, czy konfesja miała wpływ na utrzymanie polskości na tym specyficznym terenie. Kaszuby są bowiem regionem Polski, w którym tradycje kaszubskie i polskie (w tym również religijne) kultywuje się jako równoważne. Opierając się na opracowaniach historycznych i językoznawczych oraz wybranych tekstach literackich, można założyć, że naród kaszubski dzięki przynależności do Kościoła katolickiego nie uległ germanizacji, jak to miało miejsce na ziemi pomorskiej, zdominowanej w XIX w. przez protestantyzm.
\end{abstract}

Słowa kluczowe: historia i granice Kaszub, Pomorze Zachodnie, Pomorze Wschodnie, język kaszubski, Kościół katolicki, kulturkampf, Florian Ceynowa, Hieronim Derdowski, Aleksander Majkowski, polskość na Kaszubach.

\section{Ad fontes...}

Najwcześniejsze wzmianki o Kaszubach i ich krainie pojawiły się w źródłach pisanych w XIII w. Po raz pierwszy nazwa Cassubia występuje w bulli papieskiej Grzegorza IX z 1238 r. i odnosi się do terenów znajdujących się na wschód od Odry. W tym też dokumencie książę szczeciński Bogusław I jest tytułowany księciem Kaszub. Pierwsze zapisane informacje o Kaszubach dotyczą zatem obszaru, na którym władzę sprawował ród Gryfitów. Pradawna Cassubia, sytuowana na najstarszych mapach, obejmuje jednak nie Pomorze Zachodnie, lecz obszar Pomorza Środkowego. Natomiast w XVI w. nazwa ta była już odnotowywana na Pomorzu Gdańskim ${ }^{1}$.

\footnotetext{
${ }^{1}$ Na marginesie można w tym miejscu zaznaczyć, że podział na Pomorze Zachodnie i Wschodnie istniał od najdawniejszych czasów. Kaszubi nigdy nie stworzyli jednolitego państwa. Być może gdyby w przeszłości powstał duży ośrodek miejski na Pomorzu Środkowym, historia ziem nadbałtyckich wyglądałaby inaczej. W sytuacji gdy władza skupiała
} 
W XII w. rozpoczęła się na Pomorzu kolonizacja na prawie niemieckim. $\mathrm{W}$ praktyce oznaczała ona przenoszenie osad z prawa polskiego na niemieckie. Nowemu prawu podporządkowali się zarówno książęta zachodniopomorscy, jak i polscy książęta gdańscy. W kontekście ówczesnej kolonizacji mówi się czasem o germanizacji. Niemniej germanizacja kojarzy się ze zjawiskiem opresyjnym, znanym z XIX w., i dlatego w odniesieniu do średniowiecza właściwszym pojęciem jest kolonizacja (Słomczyński, Obracht-Prondzyński 2016).

Rozwój średniowiecznych miast łączył się z importem kultury i cywilizacji niemieckiej, która była traktowana jako lepsza, stwarzająca szanse rozwojowe i dająca wymierne profity. Sytuacja ta trwała przez całe stulecia, a jej skutkiem była całkowita germanizacja zachodniopomorskiej dynastii Gryfitów. W miastach lokowanych na prawie niemieckim obowiązywały tzw. paragrafy wendyjskie, które dotyczyły wszystkich Słowian, nazywanych przez Niemców Wendami i mieszkających na wschód od nich. Zgodnie z paragrafami wendyjskimi każdy, kto był pochodzenia słowiańskiego, w miastach lokowanych na prawie niemieckim nie mógł mieć praw obywatelskich (Słomczyński, Obracht-Prondzyński 2016). W konsekwencji przepisy te wprowadzały zakaz obejmowania urzędów miejskich przez Słowian (Kaszubów) i przyjmowania ich do cechów rzemieślniczych. Na przykład „w 1564 roku cech kowali [w Kołobrzegu - przyp. K.K.-Z.] zagwarantował sobie w statucie, że ludność pochodzenia słowiańskiego nie będzie przyjmowana" (Kroczyński 1979, s. 27). Antysłowiańskie paragrafy wprowadzano także w należących do Polski od końca XV w. miastach wschodniopomorskich, w których dominował żywioł niemiecki (np. w Gdańsku). Wspomniane paragrafy były wyrazem walki ekonomicznej, która rozgrywała się między ludnością słowiańską a niemiecką - w praktyce uniemożliwiały one awans ludności słowiańskiej i przyspieszały proces germanizacji.

Obok miast lokowanych na prawie niemieckim istniały również miasta na prawie polskim. Czasami funkcjonowały one obok siebie. Tak było na przykład w Słupsku, gdzie istniały dwa organizmy miejskie. Niemniej, porównując mapy Kaszub co 50 lat - począwszy od XII w. - można zauważyć, że zasięg kaszubszczyzny powoli przesuwał się na wschód (ryc. 1). Była ona wypierana nie tyle przez mieszkańców, ile przez język niemiecki i przejmowanie kultury niemieckich osadników (Słomczyński, Obracht-Prondzyński 2016). Fakt, że napływali oni masowo na obszar księstwa zachodniokaszubskiego - a byli wśród osadników przedstawiciele wszystkich stanów, czyli rycerze, duchowni, mieszczanie i chłopi - spowodował, że z biegiem czasu na zaanektowanych terenach zdobyli pozycję

się w ośrodkach usytuowanych „po bokach” Pomorza, nie można było dobrze zarządzać całym terytorium. 
dominującą. Dowodem ich przewagi były choćby wspomniane wcześniej paragrafy wendyjskie. Proces spychania żywiołu kaszubskiego na tereny Pomorza Wschodniego, czyli na współcześnie kojarzone z Kaszubami, stanowiącymi część Pomorza Gdańskiego i mającymi wyraźne granice, trwał kilka wieków.

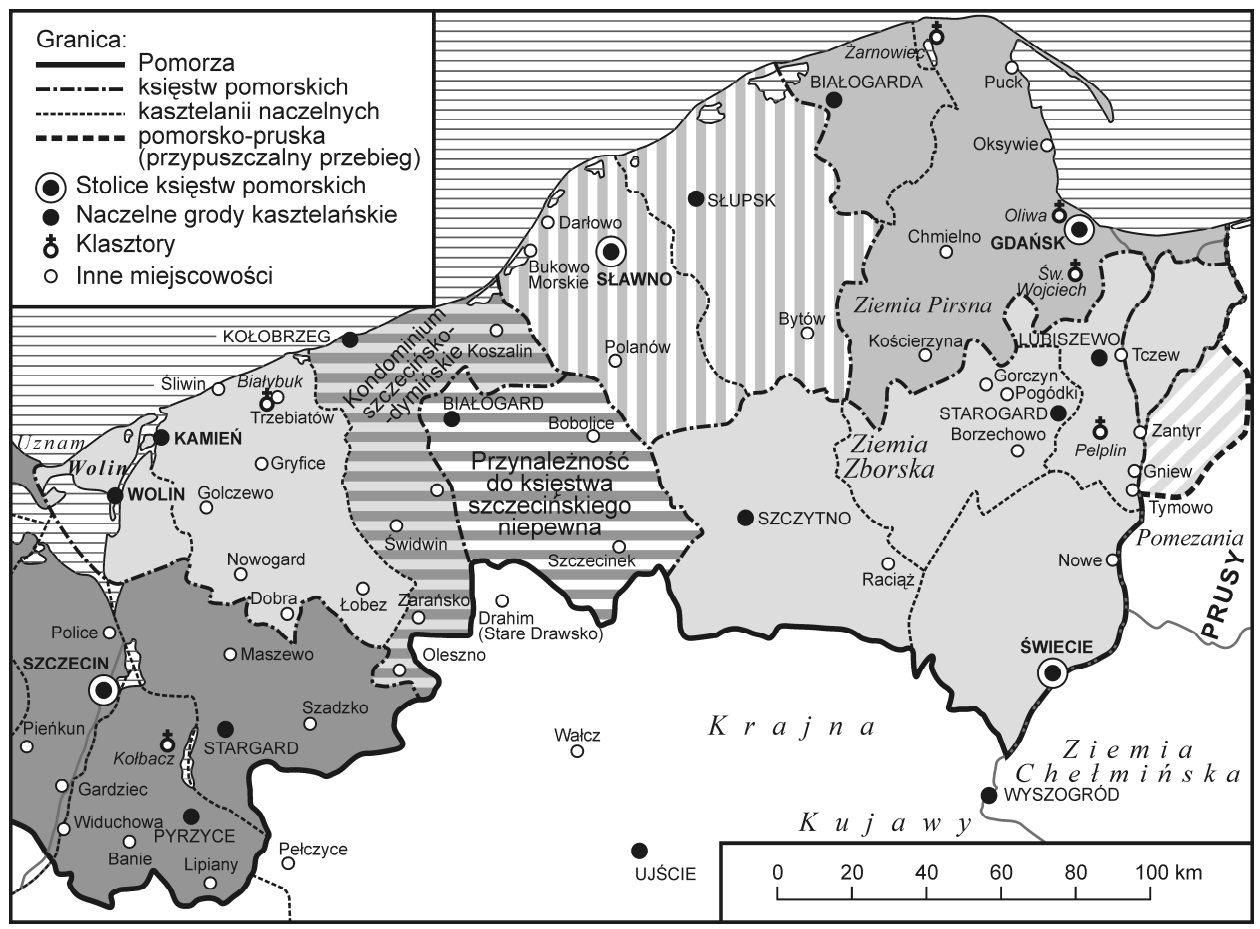

Ryc. 1. Kaszuby ok. 1200 r. według Gerarda Labudy Źródło: G. Labuda (2000), mapa między s. 104 a s. 105

Rozbieżność geograficznej lokalizacji Kaszub nurtuje badaczy od wielu dziesięcioleci. Hipotezę, że ,przesunięcie” nazwy z zachodu na wschód było skutkiem masowej migracji Kaszubów w związku z germanizacją, w ostatnich dekadach wypiera nowsza teoria, według której nazwa ta tylko ,pozornie wędrowała, gdyż zgodnie z rytmem szerzącej się od schyłku XIII w. germanizacji właściwie zamierała [...] w swoich starych matecznikach" (Labuda 1996, s. 99). Zwolennikiem nowej teorii był Gerard Labuda, który zamieranie nazwy kojarzył z powolnym zanikaniem „świadomości etnicznej ludności słowiańskiej w całej Meklemburgii i na Pomorzu Zachodnim" (Labuda 1996, s. 99). Labuda zakładał, że teren współczesnych Kaszub to resztki znacznie większego terenu, który rozciągał się pomiędzy ujściami Odry i Wisły. Przyjmując powyższą hipotezę, należy założyć, że 
w ciągu ostatniego tysiąclecia obszar Kaszub uległ znacznemu zmniejszeniu, przede wszystkim na zachodzie oraz w mniejszym zakresie na południu i południowym wschodzie.

Omawiając zagadnienia związane $\mathrm{z}$ historią ziem nadbałtyckich, należy pamiętać, że w średniowieczu Kaszubi wytworzyli własną państwowość. Niestety wschodniokaszubskie księstwo (położone na Pomorzu Gdańskim) miało zbyt krótki żywot, by mogło odegrać istotną rolę w dziejach regionu, a istniejące do połowy XVII w. księstwo zachodniokaszubskie szybko uległo (jak już wyżej zasygnalizowano) germanizacji.

Losy Pomorza Gdańskiego łączą się z testamentem Bolesława Krzywoustego. Na mocy tego dokumentu od 1138 r. wchodziło ono w skład dzielnicy senioralnej. Za pośrednictwem namiestników władzę nad Pomorzem Gdańskim sprawowali Piastowie. Z czasem owi administratorzy zaczęli się uniezależniać. Pierwszym namiestnikiem, który pojawia się w źródłach historycznych, jest Sobiesław. Uważa się go za protoplastę rodu Sobiesławowiców, panującego na Pomorzu Gdańskim do końca XIII w. Najwybitniejszym przedstawicielem tej dynastii był Świętopełk II Wielki (władający w latach 1220-1266), który w tradycji Kaszubów zajmuje szczególne miejsce (ryc. 2). Jego rządy w księstwie wschodniopomorskim to okres prosperity, którego wymownym znakiem było zrzucenie zwierzchnictwa Piastów w 1226 r. Świętopełk doprowadził do rozkwitu i rozwoju gospodarczego swojego państwa. Władca ten fundował klasztory i sprowadzał zakony; m.in. osadził w Gdańsku dominikanów i pozyskał protekcję papieża. Pod koniec życia na wzór Lubeki Świętopełk nadał Gdańskowi prawa miejskie.

Mściwój II, syn i następca Świętopełka, kontynuował politykę ojca. Jednak w sytuacji zagrożenia ze strony Brandenburgii w 1282 r. zawarł w Kępnie układ o przeżycie z Przemysłem II. W konsekwencji tej umowy w 1294 r., po bezpotomnej śmierci Mściwoja II, doszło do zjednoczenia przez księcia wielkopolskiego Pomorza Gdańskiego i Wielkopolski². Układowi w Kępnie nowożytni działacze kaszubscy przypisywali znaczenie symboliczne, które interpretowali jako akt dobrowolnego włączenia się Kaszubów w budowę zjednoczonego państwa polskiego. W tym kontekście nie należy jeszcze mówić o identyfikacji lub utożsamianiu się Kaszuby z Polakiem, niemniej już na podstawie tego rodzaju przesłanek można stwierdzić, że polityka narodu kaszubskiego miała propolski kierunek.

Proces germanizacyjny Pomorza - i to w stosunku do całej ludności tego obszaru - przyspieszyła reformacja. Ruch religijny zapoczątkowany wystąpieniem

${ }^{2}$ Rok później, w 1295, dzięki zjednoczeniu tych dzielnic Przemysł II mógł się koronować na pierwszego króla Polski po rozbiciu dzielnicowym. 
Ryc. 2. Pomnik Świętopełka II

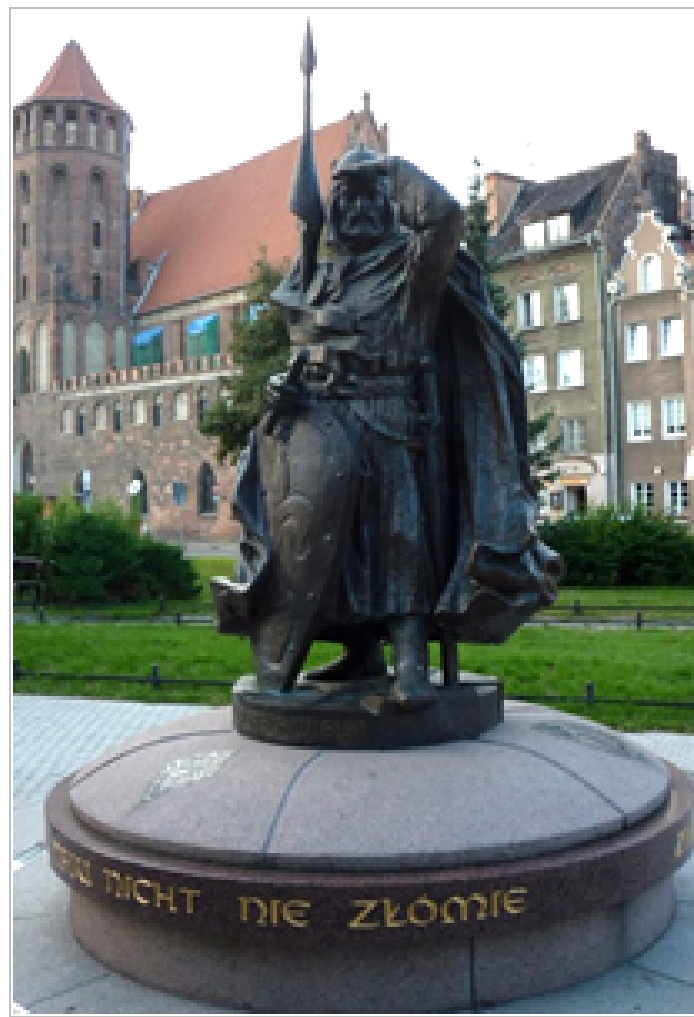
Źródło: fot. K. Krawiec-Złotkowska

Marcina Lutra w 1517 r. w Wittenberdze programowo wprowadzał posługiwanie się językiem ludu. Ewangelizacja społeczeństw ówczesnej Europy miała być zgodna z zasadami wynikającymi bezpośrednio z Biblii (a nie z postanowień soborów czy bulli papieskich) i odbywać się w językach narodowych. Założenia te spowodowały, że w całej Europie zaczęły być dostępne przekłady tekstów religijnych na lingua vulgaris. Idee Lutra dotarły z Niemiec na Kaszuby stosunkowo szybko i stały się popularne zwłaszcza w miastach zdominowanych przez ludność pochodzenia niemieckiego. Książęta kaszubscy z dynastii Gryfitów, którzy panowali w Księstwie Pomorskim (czyli na Kaszubach zachodnich), niemal od razu po pojawieniu się nowej religii zaakceptowali ją. Oficjalnie konwersję na luteranizm zatwierdzono w 1534 r. na zjeździe stanów pomorskich w Trzebiatowie. Tym samym Kaszubi z obszaru księstwa Gryfitów stali się luteranami ${ }^{3}$. Swoją tożsamość zachowali jedynie Kaszubi mieszkający w środkowo-wschodniej części pań-

${ }^{3}$ Jednym z głównych przedstawicieli ruchu reformacyjnego na wspomnianym terytorium był Jan Bugenhagen, przyjaciel Lutra i autor historycznego dzieła Pomerania. 
stwa Gryfitów, czyli na terenie znajdującym się na wschód od Kołobrzegu (lub od Koszalina). Reformacja doprowadziła do podziału ludności kaszubskiej na dwie grupy - ewangelicką i katolicką (ryc. 3).

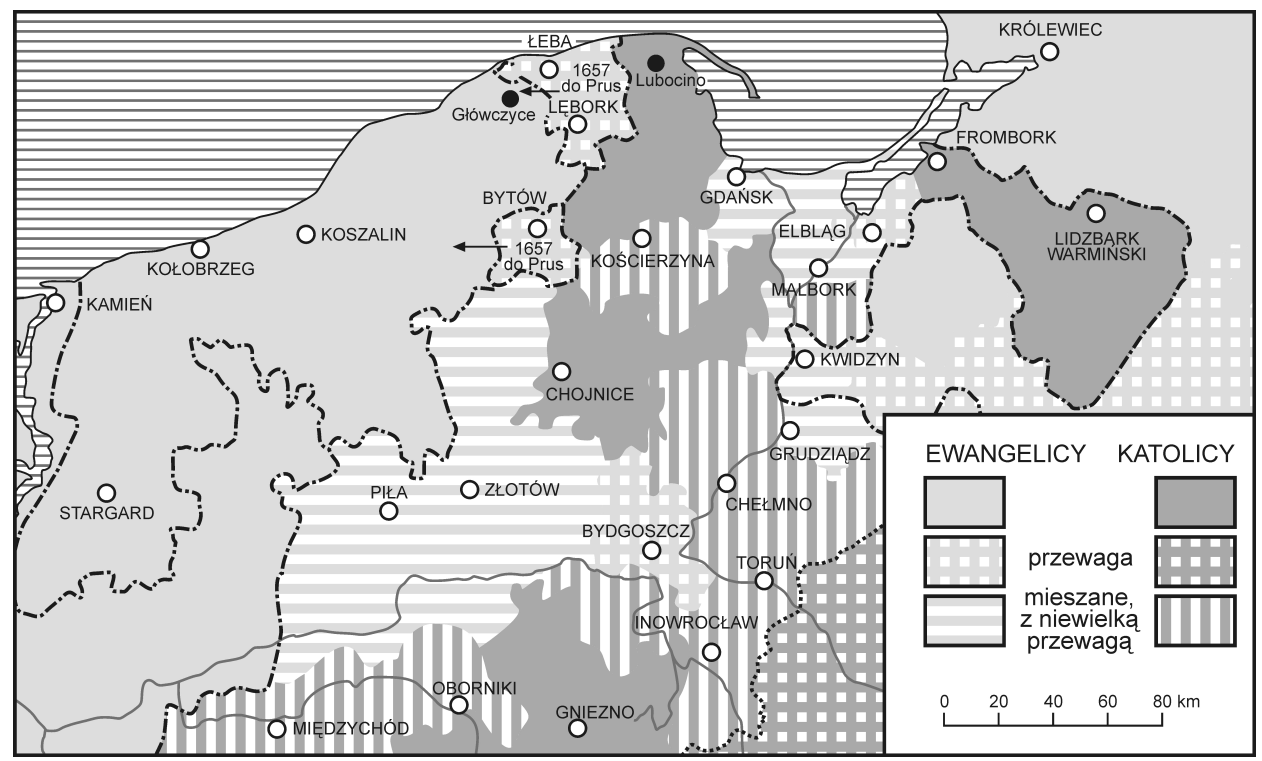

Ryc. 3. Struktura wyznaniowa na Pomorzu w końcu XIX w.

Źródło: J. Gburczyk, Historia Leby. Kościót i reformacja: https://historialeby. pl.t//Ko\%26\%23347\%3Bci\%F3\%26\%23322\%3B-i-reformacja.htm

Do dziś brakuje konsensusu w kwestii języka liturgii w Kościele protestanckim na Kaszubach zachodnich. Większość historyków jest zdania, że na ogół językiem liturgicznym w tych kościołach był niemiecki, natomiast dla ludności kaszubskiej, nieznającej go, mszę odprawiano w języku polskim lub kaszubskim. Pomimo że współcześnie dominuje hipoteza, że językiem liturgii był tam język polski (Szultka 1991), to w źródłach pruskich wymieniany jest również kaszubski (Borzyszkowski, Mordawski, Treder 1999). W tym kontekście bardzo ważne wydaje się rozporządzenie z 1734 r. wydane przez króla pruskiego Fryderyka Wilhelma I, które dotyczyło spraw katechizacji i szkolnictwa. W dokumencie tym stwierdzono, że co niedzielę pastor ma głosić kazania zarówno po niemiecku, jak i po kaszubsku (albo po polsku), a katechizacja musi być prowadzona w obu tych językach. Tym samym do liturgii kościelnej trafił język polski lub lokalny jego wariant, czyli kaszubski. Równocześnie pojawiło się zapotrzebowanie na teksty religijne pisane w językach ludu. Wyzwanie to podjęli żyjący na przełomie wieków XVI i XVII w. 
pastorowie Szymon Krofey z Bytowa i Michał Mostnik (Brüg-gemann), zwany Pontanusem ze Słupska. W konsekwencji mamy na Pomorzu starokaszubskie zabytki językowe. Są nimi Duchowne piesnie Dra Marcina Luthera i inszich naboznich mężów Krofeya z 1586 r. oraz Maly Catechism Niemiecko Wándalski abo Slowięski z 1643 r. Pontanusa. Nie są to, co prawda, źródła stricte kaszubskie, lecz teksty polskojęzyczne zawierające kaszubizmy, niemniej dzieła Krofeya i Mostnika uważa się za teksty protokaszubskie, które zapoczą-tkowały literaturę kaszubską na długo przed pojawieniem się utworów Floriana Ceynowy i Hieronima Derdowskiego w przestrzeni kaszubskiego życia pub-licznego.

Inaczej sytuacja przedstawiała się na Kaszubach wschodnich, wchodzących w skład Prus Królewskich, które należały do Polski. Na tym obszarze luteranizm trafił na podatny grunt głównie w miastach, zwłaszcza w Gdańsku. Nową religię przyjmowały nie tylko osoby pochodzenia niemieckiego, ale i Kaszubi. Nie był to proces wymuszany. Szlachta kaszubska nie miała oporów przed konwersją na luteranizm lub na drugi odłam protestantyzmu - kalwinizm. Reformacja odcisnęła piętno nawet na kaszubskiej ludności chłopskiej. Niemniej pod koniec XVI w., a szczególnie w XVII w., gdy nastąpiły intensywne działania kontrreformacji, rozpoczął się proces powrotu miejscowej ludności do wyznania rzymskokatolickiego. W konsekwencji na obszarze Prus Królewskich większość Kaszubów zachowała wiarę katolicką, chociaż jeszcze w drugiej połowie XVII w. działały tam czysto kaszubskie (pod względem etnicznym) zbory protestanckie (np. w Lubocinie).

W kontekście tamtych zjawisk interesujący jest epizod historyczny związany z wygaśnięciem dynastii zachodniopomorskiej. Po bezpotomnej śmierci ostatniego z Gryfitów, księcia Bogusława XIV, ziemię bytowsko-lęborską przyłączono do Prus Królewskich, czyli do Rzeczpospolitej. Był to okres stosunkowo krótki, obejmujący lata 1637-1657, ale brzemienny w skutki. Na wskazanym terenie zjawił się wówczas polski starosta, po czym nastąpiła gwałtowna rekatolizacja ludności ${ }^{4}$. Zaowocowała ona tym, że Kaszubi deklarujący tylko wyznanie katolickie przetrwali na tym terenie aż do czasów współczesnych. Nadmienić trzeba, że językiem liturgii w Kościele katolickim była wówczas łacina, co nie przeszkadzało wiernym identyfikować się właśnie z tym wyznaniem.

Losy Kaszubów, którzy złączyli się z Kościołem ewangelickim, potoczyły się zgoła inaczej. Na początku ruch reformacyjny przyczynił się do pewnego ożywienia kaszubskiego ducha. Niemniej w następnych wiekach nastąpiła eskalacja

\footnotetext{
${ }^{4}$ Wtedy również prawa miejscowej szlachty zostały zrównane z prawami szlachty polskiej.
} 
nacisków germanizacyjnych, stosowanych przez władze pruskie, w tym również kościelne, co wywołało negatywne dla Kaszubów skutki. Reformacja stała się bowiem jednym z głównych czynników wynaradawiających ludność kaszubską. Ruch ten należy łączyć z radykalną germanizacją na Pomorzu Zachodnim, która nastała w XVIII w. W zakresie polityki kościelnej charakterystyczne były wówczas działania germanizacyjne pastora Christiana Wilhelma Hakena, którego prymarnym celem stało się jak najszybsze usunięcie języka kaszubskiego nie tylko z praktyk religijnych kaszubskiego ludu, ale i z życia publicznego tej społeczności. Kierunek antykaszubskich działań podejmowanych przez pastora Hakena był zgodny z polityką pruskich władz kościelnych. Kaszubi sprzeciwiali się tej polityce i protestowali przeciw wprowadzeniu języka niemieckiego do przestrzeni ich życia religijnego i publicznego. Polityka germanizacyjna przyniosła oczekiwane przez Niemców rezultaty dopiero w drugiej połowie. XIX w., w czasie kulturkampfu, gdy ostatecznie wyrugowano z kościoła język kaszubski. Ostatnie nabożeństwo w tym języku dla kaszubskich ewangelików odbyło się w Główczycach na ziemi słupskiej u schyłku XIX w. Można stwierdzić, że właśnie wtedy Kaszubi ewangelicy całkowicie zasymilowali się z Niemcami. W konsekwencji przetrwali tylko Kaszubi katolicy, a rekatolizacja tego narodu, przeprowadzona w latach 1637-1657, miała w tym przypadku znaczenie fundamentalne.

W związku z historią nadbaltyckiego ludu, ziemie, które on zamieszkuje, określano czasami jako wędrujące Kaszuby. W ustaleniu, jaki obszar rzeczywiście zajmowała ta nacja w XIII-XV w. (i wcześniej) pomocne są badania językoznawcze. Bazę źródłową naukowej eksploracji stanowią nazwy własne - imiona i nazwiska osób, nazwy miejscowości, rzek i jezior, zawarte w dawnych dokumentach pisanych po łacinie i niemiecku. Wyniki tego typu badań wskazują na językową spójność całego Pomorza od dolnej Wisły po dolną Odrę. Niemniej można odnotować różnice dialektalne i ze względu na to, że niektóre właściwości dialektów pomorskich zawierają cechy występujące na Połabiu, a inne w Polsce, kaszubszczyznę określa się czasem jako język przejściowy między polszczyzną a dialektami połabskimi (Piskorski 2002, s. 210). Nazwy języka, którym posługują się mieszkańcy Kaszub to: kaszëbsczi jãzëk, kaszëbskô mòwa, pòmòrsczi jãzëk, kaszëbskò-stowińskô mòwa. Uwzględniając region i historię, należy stwierdzić, że jest to mowa zachodniosłowiańska i lechicka o spornym statusie - w zależności od przyjętych kryteriów uznaje się ją za odrębny język lub dialekt języka polskiego. Kaszubski jest jedyną pozostałością słowiańskich dialektów pomorskich.

Używany współcześnie pisany język kaszubski jest ewolucją formy zaproponowanej w 1879 r. przez F. Ceynowę w podręczniku Zarés do Grammatikj Kašébsko-Slovjnskjè Mòvé. W spisie powszechnym z 2002 r. użytkowanie języka kaszuskiego 
jako pierwszego zadeklarowało 52665 osób $^{5}$. Nie pokryły się te dane z deklaracjami określającymi narodowość kaszubską, którą potwierdziło 5062 obywateli, czyli bardzo mało, gdyż jedynie ok. 1\% całej społeczności kaszubskiej (ryc. 4).

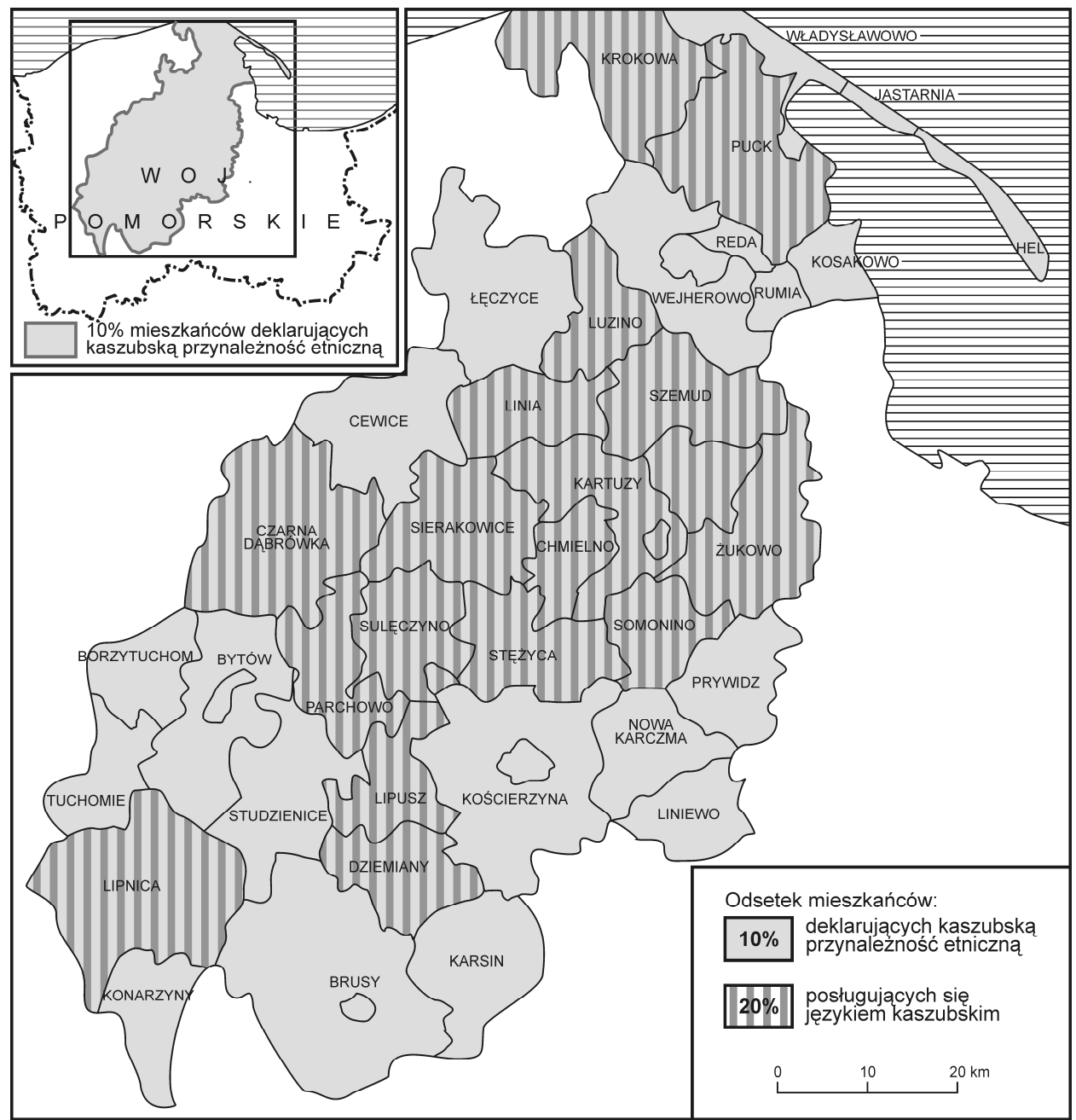

Ryc. 4. Udział procentowy osób posługujących się językiem kaszubskim i deklarujących kaszubską przynależność etniczną

Źródło: http://odwiedzkaszuby.pl/granice-kaszub-na-przestrzeni-wiekow/

${ }^{5}$ Ludność wedlug narodowości, płci oraz miejsca zamieszkania w 2002 r., Główny Urząd Statystyczny, https://stat.gov.pl/spisy-powszechne/narodowe-spisy-powszechne/na rodowy-spis-powszechny-2002/wyniki-narodowego-spisu-powszechnego-2002-narodowo sci-oraz-jezyka/ (18.11.2017). 
Mimo to polskie prawo przyznało językowi kaszubskiemu, jako jedynemu w Polsce, status języka regionalnego ${ }^{6}$. Dzięki temu młodzież przystępująca do nowej matury może ją zdawać w języku kaszubskim.

\section{Kulturkampf}

Objęcie stanowiska kanclerza Rzeszy przez Ottona von Bismarcka spowodowało zaostrzenie polityki germanizacyjnej na polskich ziemiach. Była ona skierowana głównie przeciw polskiemu szkolnictwu i Kościołowi. Był to okres kulturkampfu, czyli rozpoczętej w 1871 r. walki o czystość kultury niemieckiej, która swym zasięgiem objęła również Kaszuby. W latach 1872-1874 prawie całkowicie wyrugowano ze szkół język polski, usuwano z nich również nauczycieli Polaków, a na ich miejsce zatrudniano Niemców. W dniach 11-14 maja 1873 r. pruski parlament (Landtag) uchwalił pakiet ustaw wymierzonych przeciw Kościołowi katolickiemu. Były to tak zwane ustawy majowe. Stanowily one rdzeń antykatolickiej polityki kulturkampfu. W 1876 r. wycofano ostatecznie język polski z sądownictwa i urzędów na całym obszarze ziem zaboru pruskiego. Walka przeciw Kościołowi miała za zadanie osłabienie jego wpływu na społeczeństwo.

Kulturkampf na ziemiach polskich, znajdujących się pod panowaniem pruskim, wyraził się w powiązaniu polityki germanizacyjnej z polityką antykatolicką. Kościoły protestanckie, zdominowane przez żywioł niemiecki, stały się wówczas narzędziem władz państwowych i włączyły się $\mathrm{w}$ wynaradawiającą walkę z szeroko rozumianą polskością. Paradoksalnie polityka ta, polegająca na eskalacji antypolskich (a na Pomorzu również antykaszubskich) działań, zrodziła opór i zjednoczenie całej ludności w pokojowej walce z niemczyzną ${ }^{7}$.

${ }^{6}$ Ustawa z dnia 6 stycznia 2005 r. o mniejszościach narodowych $i$ etnicznych oraz o języku regionalnym, DzU 2005, nr 17, poz. 141.

${ }^{7} \mathrm{Na}$ początku XX w. władze pruskie jeszcze bardziej zintensyfikowały walkę z polskością, uchwalając tak zwane ustawy wyjątkowe. Pierwsza, z 1904 r., wprowadzała zakaz tworzenia nowych osad rolnych bez pozwolenia władz niemieckich. W praktyce nie można było stawiać żadnych nowych budynków. W tym kontekście do rangi symbolu urosła postać Michała Drzymały z Podgradowic, który przez kilka lat mieszkał w wozie. Nie mając pozwolenia na postawienie domu, przestawiając co jakiś czas wóz z miejsca na miejsce, podjął walkę z biurokracją i prawem niemieckim. Niestety w 1910 r. Drzymała został zmuszony do sprzedania ziemi. Można wiązać ten fakt z prawem do przymusowych wywłaszczeń polskich majątków, które od 1908 r. przysługiwało Komisji Kolonizacyjnej. W tym też czasie przyjęto ustawę o zgromadzeniach (tak zwaną ustawę kagańcową), która dopuszczała możliwość odbywania zebrań i zgromadzeń wyłącznie w języku niemieckim. 
W połowie XIX w. do zahamowania procesów germanizacyjnych na Kaszubach przyczynił się znacząco Florian Ceynowa, nazywany „ojcem literatury kaszubskiej i regionalizmu pomorskiego" (zob. Bukowski 1950, Karnowski 1997, Kalinowski 2009). To jego działalność polityczna i publicystyczna ożywiła na nowo ducha kaszubskiego. I chociaż w Warszawie i innych miastach położonych w głębi kraju podejrzewano kaszubskiego działacza o radykalne poglądy separatystyczne, które w praktyce mogłyby doprowadzić do oderwania Kaszub od macierzy, to jego zasługi na polu walki z kulturkampfem są niekwestionowane.

\section{Idea odrodzenia Kaszub Floriana Ceynowy}

Walka ideowa F. Ceynowy była skoncentrowana na odrodzeniu Kaszub. Zrodziła się ona w atmosferze afirmacji kultury słowiańskiej (a ściślej mówiąc: kaszubskiej) wśród studentów (do których grona młody Kaszuba należał) i profesorów słowiańskich Uniwersytetu Wrocławskiego (Borzyszkowski 2011, s. 32). Podążając za tą „kaszubskofilską” ideą, F. Ceynowa opublikował w 1850 r. szkic Kile stov wó Kaszebach e jich zemi przez Wójkasena (...). Tudzież rzecz o języku kaszubskim ze zdania sprawy Prajsa i Rozmòwe Pòlôcha z Kaszëbą, a w 1868 r. została wydana jego Rozmòwa Kaszëbë z Pòlôchã. Teksty Floriana Ceynowy nie są napisane czystą ${ }^{8}$ kaszubszczyzną, niemniej pojawienie się tego autora w ówczesnej przestrzeni życia publicznego miało decydujący wpływ na żywe zajęcie się Kaszubami przez środowiska intelektualne $\mathrm{z}$ innych ziem polskich. Ceynowa „uznał za stosowne i potrzebne pisać po kaszubsku, a w dodatku wystąpił od razu z programem odrębności narodowej Kaszubów" (Ramułt 1893, s. XXXVIII). On też zainicjował nową epokę w dziejach ruchu regionalnego na Kaszubach. Był wówczas człowiekiem młodym i energicznym, któremu bliskie były - zgodne z duchem romantyzmu - hasła i idee poszukiwania źródeł tradycji narodu w kulturze ludowej. Właśnie dlatego zaangażował się w badanie etnogenezy Słowian. W ludowych praktykach, obrzędowości, w wiejskim folklorze i gminnych pieśniach doszukiwał się jej korzeni. Jego życiowym credo było doprowadzenie do odrodzenia kulturowego całych Kaszub. Docierał do ludu, w którym upatrywał fundamentów kaszubskiej tożsamości, i krytykował tych, którzy wstydzili się mowy ojców. $Z$ tego też powodu zaczął pisać w poniewieranym dotąd i często

${ }^{8}$ Epitet czysta w odniesieniu do języka kaszubskiego jest tu oczywiście użyty z pewnym zastrzeżeniem, należy bowiem uwzględniać fakt, że pisma F. Ceynowy miały charakter pionierski, a pisownia kaszubska przez kilka kolejnych dziesięcioleci nie została jednoznacznie ustalona. 
wzgardzanym języku, ujawniał nieznane fakty historyczne, odsłaniał najchlubniejsze karty z dziejów Księstwa Pomorskiego (Krawiec-Złotkowska 2017a, s. 538559). Za wszelką cenę pragnął swym krajanom wpoić dumę szczepową (Samp 2007, s. 7).

Idea Ceynowy nie zyskała wówczas poklasku, ponieważ sam twórca „szkodził jej bardzo wiele, zadzierając z duchowieństwem i czyniąc sobie wrogów naokól" (Ramułt 1893, s. XXXVIII). Najbardziej naraził się Ceynowa opinii publicznej, biorąc udział w 1867 r. w Zjeździe Słowiańskim w Moskwie, który wszyscy Polacy zdecydowanie krytykowali $\mathrm{z}$ racji tego, że odbył się po upadku powstania styczniowego. Po tym wydarzeniu okrzyknięto Ceynowę panslawistą, zarzucano mu prorosyjskie sympatie i agitację na rzecz Rosji. Posądzano go nawet o bycie ateistą i prowadzenie niemoralnego trybu życia (Samp 2007, s. 7; Krawiec-Złotkowska 2017a, s. 538-559). Mimo niekorzystnej koniunktury działacz kaszubski ostatecznie osiągnął postawiony sobie cel. Jego idee wywołały ferment w ówczesnych poglądach społecznych. Dzięki nim lud kaszubski obudził się z letargu i odzyskał wiarę we własne siły, tak potrzebne w walce z polityką kulturkampfu. Ceynowa opracował program narodu kaszubsko-słowiańskiego, jednak to nie on ostatecznie ukształtował kaszubski i jednocześnie propolski, a co za tym idzie również prokatolicki światopogląd tego nadbałtyckiego ludu.

\section{Propolskie idee Hieronima Derdowskiego}

Propolską postawę w drugiej połowie XIX w. prezentował działacz kaszubski - równie wybitny jak F. Ceynowa - Hieronim (Jarosz) Derdowski. Bez wątpienia znał on drukowane po kaszubsku książeczki swojego poprzednika, nie był jednak wierny ideowemu nauczycielowi i nie podzielał jego radykalnych poglądów o Kaszubach. H. Derdowski postulował łączność Kaszub i Polski. Łączność ta wyrażała się jego zdaniem również w przynależności do Kościoła katolickiego, w którym Kaszubi (mimo liturgii w języku łacińskim, a nie kaszubskim) widzieli ostoję polskości i kaszubskości, postrzeganych jako nierozerwalne. Derdowski, mimo odmiennych poglądów, po śmierci pioniera i orędownika „sprawy kaszubskiej” (Krawiec-Złotkowska 2017b, s. 91-109) uczcił Ceynowę wierszem opublikowanym w „Warcie”. Jednocześnie w tym utworze, dedykowanym „nauczycielowi”, ujawnił własny propolski program ideowy, który powtarzał we wszystkich rozważaniach o Kaszubach. Wyraził go znamiennymi słowami: „Ni ma Kaszub bez Polonii a bez Kaszub Polsci!" (Derkowski 1880).

Propolskie postulaty Derdowskiego dostrzegamy w poemacie O panu Czorlińscim, co do Pucka po sece jachol oraz w innych tekstach jego autorstwa, np. 
w utworze Kaszuba pod Widnem. Na dwusetna reczeznę oswobodzenia mniemców i krześcyjaństwa od turećciego jerzma w roku Pańscim 1683. Dzieła te ujawniają postawę polonofilską i przywiązanie autora do tradycji Kościoła rzymskokatolickiego. Autor nie tylko żywi sympatię dla „braci Polaków”, ale wręcz utożsamia się z nimi i z Kościołem katolickim. Fragmentów, które potwierdzają tę opinię, jest wiele. Na przykład bohater poematu $O$ panu Czorlińscim... „egzamin” z wiedzy katechetycznej zdaje na podstawie „kaszubściego swiętego pisma”, które bez wątpienia jest Pismem Świętym używanym we wspólnocie katolickiej. O topografii Kaszub, przedstawianych w utworze jako Ziemia Święta, opowiadał Czorlińscie$\mathrm{mu}$ kwestarz Leon, franciszkanin $\mathrm{z}$ wejherowskiego konwentu. Samo miejsce, w którym rozwija się ów wątek fabularny, jest znaczące, bo przecież rzecz się dzieje w nekropoli książąt kaszubskich, katedrze oliwskiej - starej świątyni pomorskiej (Krawiec-Złotkowska 2012, s. 117-118). Można powiedzieć, że w dziele Derdowskiego nakładają się dwa porządki - sakralny i profaniczny. Oba jednak są podporządkowane propolskiemu i prokatolickiemu myśleniu ich autora.

Spolszczona w poemacie mowa ojców, wędrówka ze szlachcicem i gościna u Dąbrowskiego w „Kantrzenie”, wspomnienia o polskiej historii i władcach, polskie krajobrazy, mówienie o ziemi żarnowieckiej jako o "swięty polści zemni”, przez którą przepływa ,polści strudzi czesty, polści wode", a w jego pobliżu jest również „polści gospoda”, ,pomniatki po krolu Sobjeścim”, wreszcie legendarny Krak (z podania o Kraku i Wandzie, co nie chciała Niemca), z którego Derdowski zrobił Kaszubę Kroka, potwierdzają utożsamianie polskości z kaszubskością. W świecie przedstawionym $\mathrm{w}$ utworze pojawia się również Warszawa, której mieszkańcy, mający zgoła inną perspektywę na ziemie nadbałtyckie, kwestionowali braterstwo Polaków i Kaszubów. Bohater utworu z żalem stwierdza, że w stolicy jego pobratymców po prostu lekceważą:

Me Kaszube, jesz strzeżeme Polsci morsciech granic, A $w$ Warszawie naszy braco maja naju za nic ${ }^{9}$.

Lekceważenie i nieufność, jakich doświadczał bohater poematu od rodaków, były źródłem smutku i przykrych odczuć, gdyż będąc Kaszubą, czuł się zarazem Polakiem. Artykułuje tę kwestię wyraźnie, gdy opowiada w Pucku szynkarzowi, jak został przyjęty w stolicy:

Ciejm z kupcami we Warszawie bewol tak przed rociem,

Tej nie chcele mnie tam wierzec, że jem jech rodociem. [...]

I nie chcele mnie też wcole podac bratni dtoni,

A jo z dusza i ze sercem Polok jem, jak oni.

\footnotetext{
${ }^{9}$ Cytaty z poematu Derdowskiego według edycji: H. Derdowski (1880).
} 
Wypowiedź Czorlińsciego ujawnia polonofilską postawę Derdowskiego, którego można utożsamiać z podmiotem utworu. Najpełniej miłość Kaszuby z Wiela do Rzeczpospolitej oddaje zamieszczony w poemacie śpiewany przez głównego bohatera Marsz Kaszubski. Opiewana jest w nim historia Ojczyzny, której nieodłączną częścią są Kaszuby. Nieoficjalny hymn Kaszubów ${ }^{10}$ głosi, że mowa ojców to „polsko mowa”, a wiara przodków to „polsko wiara”. Wspomniany w niej św. Stanisław Kostka to „nasz”, czyli polski i zarazem kaszubski, święty. Pieśń wieści chwałę Kaszubów, którzy walczyli pod wodzą Jagiełły, Kazimierza IV Jagiellończyka oraz bili się ze Szwedami. Co istotne, w Marszu Kaszubskim w formie refrenu powtarzana jest sekwencja:

\author{
Nigde do zgube \\ Nie przyńda Kaszube, \\ Marsz, marsz za wrodziem! \\ Me trzymame z Bodziem.
}

Nie mamy wątpliwości, jakiego Boga dotyczą te słowa. Bohater utworu (i utożsamiający się z nim autor) ma na myśli oczywiście Boga, w którego Kaszubi wierzyli i którego wielbili w obrządku katolickim. Katolickość i polskość były dla Derdowskiego niemal tożsame - w przeciwieństwie do konfesji ewangelickiej, która kojarzyła się z niemieckością.

W kontekście omawianych tu problemów wyznaniowych na uwagę zasługuje recenzja poematu Derdowskiego zamieszczona w petersburskiej "Gwieździe" z 1882 r. (Krawiec-Złotkowska 2017a). Jej autor uważał, że przedstawiciele kaszubskiej społeczności woleliby „zrównać się z nami [Polakami - przyp. K.K.-Z.] zupełnie". Zauważył, że ówcześni Kaszubi:

[m]ówią pacierz po polsku, t.j. starają się wymawiać jak najczyściéj wedle książkowego języka, nie mają osobnych książek do nabożeństwa, oprócz tych, które ma cała Polska, i tak téż prawią u nich księżą z ambon. Co większa, mieliby to sobie za ujmę i niejakie podrzeźnianie, gdyby ksiądz w kościele po kaszubsku miał wymawiać (Gliński 1882).

Podobne „zastrzeżenie” sformułował również sam Derdowski i to już u progu swojej kariery literackiej:

Do tego pewnie nigdy nie przyjdzie, aby Kaszubi mieli czytać wyłącznie książki kaszubskie, czytają oni gazety polskie, modlą się i śpiewają z polskich książek w kościele i dobrze wszystko rozumieją, więc nie potrzeba im książek kaszubskich (Derdowski 1939, s. 41).

${ }^{10}$ Taką funkcję pieśń ta pełni również dzisiaj. Niemniej na marginesie należy zaznaczyć, że ostatnio pojawiła się na Kaszubach grupa działaczy, którzy jako hymn proponują pieśń Jana Trepczyka Zemia Rodnô. 
Opinie Derdowskiego i nieznanego z imienia recenzenta poematu $O$ panu Czorlińscim..., jak i literackie „dowody” autora z Wiela, potwierdzają ścisły związek Kaszubów z Kościołem katolickim, który - mimo liturgii w języku łacińskim - w okresie kulturkampfu i na przełomie XIX i XX w. stał się dla nich ostoją polskości (i kaszubskości zarazem).

\section{Kaszubska Ziemia Święta w dzielach Aleksandra Majkowskiego}

W utworach Aleksandra Majkowskiego znajdujemy jeszcze więcej przykładów, które dowodzą, jak ważna jest dla Kaszubów wiara. Miejsca kultu religijnego opisywane przez tego twórcę to loci bezwzględnie należące do Kościoła katolickiego. U A. Majkowskiego zyskują one wymiar wręcz mityczny. Na przykład odpowiednikiem narodowej nekropoli na Wawelu jest na Kaszubach katedra oliwska (ryc. 5) (Krawiec-Złotkowska 2012, s. 111-116).

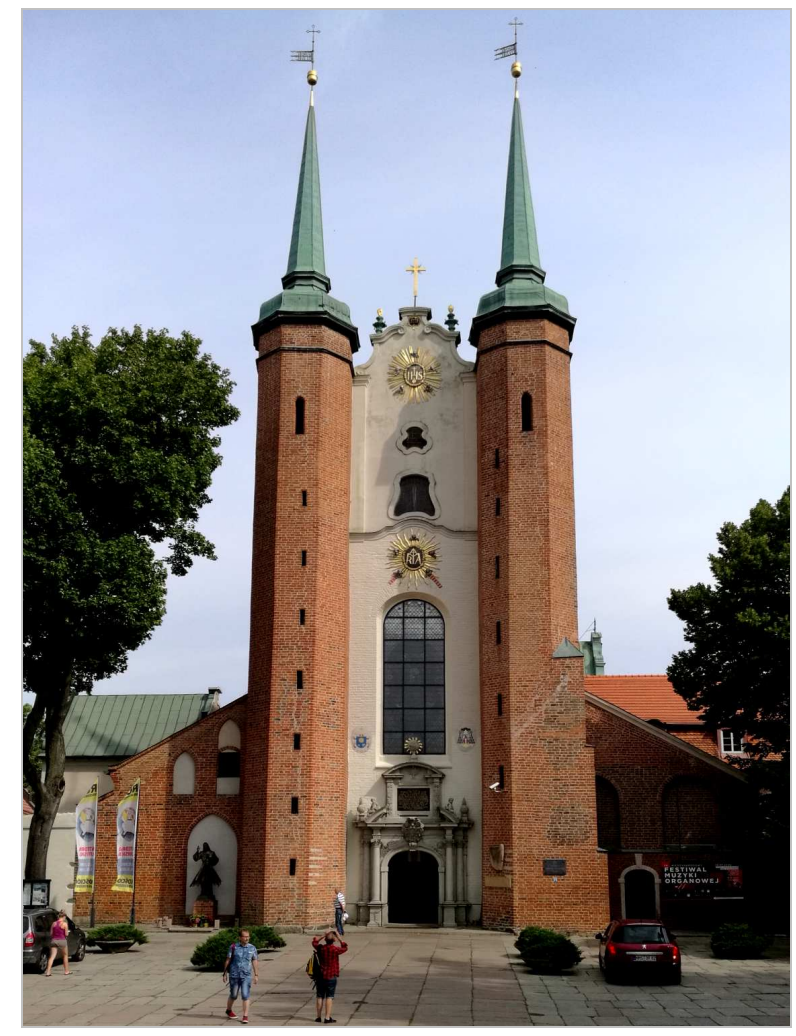

Ryc. 5. Katedra oliwska w Gdańsku Źródło: fot. K. Krawiec-Złotkowska 
Majkowski pisze o „starej świątyni pomorskiej” (tak nazywa katedrę w XIII rozdziale powieści ${ }^{11}$ ) w Pomorzanach, a po latach wspomina ją w kaszubskiej epopei Żëcé i przigòdë Remùsa ${ }^{12}$. W pierwszym wskazanym tekście w mury katedry wprowadza czytelników Lubiński. Świadomy najwyższych celów, jakie życie stawia przed jednostką i narodem, musiał zmierzyć się z bezwładem woli, porażonej słabością i brakiem wiary. Podobną walkę stoczy Remus, który wędrował po Kaszubach z taczką pełną książek, a jego celem było dotarcie do ostatnich miejsc, gdzie jeszcze żyła mowa kaszubska, do ludzi, którzy nie stracili godności i dumy pod pruskim panowaniem ${ }^{13}$. W myśl tej idei Remus przemierza całe Kaszuby - od oliwskiej katedry po ziemię Słowińców.

Tak jeden, jak i drugi bohater w murach kaszubskiej nekropolii doświadczają cudu, niejako wbrew okolicznościom i w niesprzyjających warunkach. Świątynia oliwska na przełomie XIX i XX w. była bowiem otoczona niemczyzną i nie mogła odgrywać roli narodowej inspiracji. Można powiedzieć, że była martwa. Mimo to na „ostatnich Pomorzanach" i mitycznym Remusie (uosobieniu kaszubskiego Stolema) zrobiła ogromne wrażenie. Lubiński w tym budynku właśnie zrozumiał prawdę o ciągłości historii i jej trwaniu.

Bohater Pomorzanów w katedrze oliwskiej, krocząc „po ogromnych płytach, których dumne herby i hasła $w$ granicie wyryte wytarly były nogi i kolana wiernych, noszących do tej świątyni swe troski drobne i wielkie przed oblicze Boga" (s. 111), doznał olśnienia, że nowsze nagrobki (należące do „najeźdźców, zdobywców, którzy rządzili obecnie" tą ziemią) ,[w]ytrą się jak te dawne [...] pod stopami naszego szczepu" (s. 111). Jednocześnie niemi fundatorzy i dobrodzieje kościoła i klasztoru, władcy narodu pomorskiego, ,z których zbroi i gronostajów biła chwała i potęga" (s. 111), napełniali bohatera wstydem. Wydawało mu się, że wszyscy oni, ,patrzący ze ścian, Subisławy, Mszczugowie i Świętopełk w zbroi, zwyczajni [...] kroczyć na czele hufców zbrojnych, bitnych, wolnych, warując strachem i szacunkiem granice wolnego kraju”, pytali: „Tyleż was tylko pozostało z pokolenia czarnego Gryfa?" (s. 111). Retoryczne pytanie, które zrodziło się w duszy Lubińskiego, z jednej strony przyczyniło się do pogłębienia uczucia upo-

\footnotetext{
${ }^{11}$ Cytaty z powieści Pomorzanie według edycji: A. Majkowski (1973).

${ }^{12}$ Cytaty z powieści Żëcé i przigòdë Remùsa według edycji: A. Majkowski (1966).

13 Remus w czasie swej peregrynacji po Kaszubach spotyka trzy zniechęcające go do działania upiory (Strach, Trud i Niewarto) oraz jego największego wroga - Arymana, którego Kaszubi nazywają Smętkiem. W epopei objawia się on w dwóch wcieleniach - jako cyniczny adwokat Czernik i demoniczny artysta malarz. Postać Smętka-Arymana wywiódł A. Majkowski najprawdopodobniej z historiozoficznej koncepcji Stefana Żeromskiego, zawartej w powieści Wiatr od morza (1924).
} 
korzenia $\mathrm{i}$ niemocy, ale $\mathrm{z}$ drugiej uświadomiło bohaterowi różnicę pomiędzy „wielką przeszłością a marnym i nikłym dzisiaj” (Krawiec-Złotkowska 2012, s. 115). Martwa świątynia stanowiła pomost między dawną i współczesną historią Kaszubów.

W Pomorzanach katedra oliwska była martwa do momentu, gdy zabrzmiały w niej organy. W powieści czytamy, że:

Coraz silniej się potęgowały tony [...]. Te głosy, wywołujące bratnie dźwięki w jego [Lubińskiego - przyp. K.K.-Z.] duszy, napełniwszy olbrzymie sklepienie, schodziły w dół, okrążały filary i śpiewały u ołtarzy też pieśni, które lud zbożny pomorski śpiewał od wieków. I zebrawszy całą siłę uderzały, jak huragan, jak olbrzymia fala pątników z całego Pomorza, w wielki ołtarz, gdzie w chmurach widniał symbol Trójjedynego Boga (s. 114).

Instrument obudził się, bo „uderzyła godzina w biegu dziejów”, która miała ożywić ducha Pomorza. Przy cudownej muzyce z organów i apelu dawnych przodków przed grobowcem pomorskich książąt Lubiński i jego młodzi towarzysze złożyli uroczystą przysięgę:

Na lądzie i morzu i w niezmierzonych przestrzeniach Wszechwładny Stwórco i Boże!

W obliczu ołtarzy, na prochach swych ojców przysięga młode Pomorze.

Jak dzieci sieroty, co matki nie znali, co ojca stracili na boju.

My dążąc do grobów rodzica i matki na pierwszym stanęli postoju.

I w Twoją opiekę oddajem się z wiarą, że gwiazda nad nami zapłonie.

By wiodła nas obcych wśród rzeszy narodów ku ojca i matki stronie.

I nie złożymy z rąk naszych wędrownej laski i torby pątniczej.

Aż w ziemi ojczystej, na ogniskach wygasłych, na nowo zapłoną nam znicze.

Aż wiara i język i przodków obyczaj znajdzie się w świetle ołtarzy.

Gdzie nasze proporce z srebrnymi Gryfami staną zbrojne na straży.

Jeżeli tej roty zapomni drużyna i serce w piersi zemdleje.

Niech oko ojcowskie Twe z dala jej wskaże wolności dumne wierzeje.

A kiedy odstąpi sztandaru wśród obcej świty i dworzan,

Ruń Boże, filary i przęsła świątyni na głowy ostatnich Pomorzan (s. 114).

Słowa przysięgi przypieczętował hymn Te Deum, który zabrzmiał w katedrze niemal natychmiast po jej złożeniu. Właśnie ta laudacja Stwórcy Świata - zwieńczająca w Kościele katolickim obrzędy rezurekcyjne - zapowiada niejako zmartwychwstanie ostatnich Pomorzan (Krawiec-Złotkowska 2012, s. 116).

Podobne (jak Lubińskiemu) uczucia towarzyszą w katedrze oliwskiej ostatniemu kaszubskiemu stolemowi - Remusowi, dla którego ta nekropolia była jednym z głównych celów peregrynacji. Tytułowy bohater kaszubskiej epopei odwiedza „starą pomorską świątynię", kierowany wewnętrzną potrzebą wypełnienia woli 
jego nauczycieli - pierwszego, pana Józefa (brata gospodarza, u którego Remus pracował jako parobek), oraz drugiego, w osobie księdza Pawła (z którym bohater ukrywał się przed niemieckimi żandarmami na Glonku, wyspie na jeziorze Wdzydzkim). To oni mu wpoili, że:

Każdy Kaszuba, choć tylko jeden raz w życiu, powinien odbyć pielgrzymkę do Oliwy, by się pomodlić, na grobach książąt kaszubskich. Ich mieczowi, dzielności i rozumowi zawdzięczamy, że do dziś zachowaliśmy wiarę, obyczaj i mowę ojców naszych (s. 252).

Remus pątniczy postulat wypełnia z pasją. Niestety modlitwę w oliwskiej świątyni przeżywa bardzo boleśnie. Jak Lubiński, w obliczu świetnych władców patrzących na niego spod sklepienia katedry, on również zastanawia się, ile ludowi kaszubskiemu zostało z dawnej dumy i świetności. Snuje refleksje nad tym, co się stało z dawnymi rycerzami, panami i mężnym ludem, którymi rządzili kaszubscy książęta. Pyta sam siebie, kto zgasił pamięć o nich i ich dziejach oraz zniweczył ich chwałę. Modli się w ich intencji w samotności - w dosłownym i metaforycznym znaczeniu tego słowa (Krawiec-Złotkowska 2012, s. 113). Jako stolem jest ostatnim herosem kaszubskiej ziemi i ma świadomość powierzonej mu misji ratowania ludu, który stracił swojego ducha. Intencja, którą artykułuje, gdy składa ofiarę ,na mszę świętą za dusze tu [w katedrze - przyp. K.K.-Z.] pochowanych książąt kaszubskich: Subisławów, Samborów, Świętopełków i Mestwinów" (s. 253), wzbudza zdziwienie kościelnego. Reakcja ta (i podobna do niej ze strony księdza, do którego kościelny Remusa zaprowadził) dowodzi, że pamięć o dawnych władcach i czasach świetności kaszubskiej ziemi umarła, a sama świątynia straciła siłę duchowego oddziaływania. $Z$ tego też względu miejscem inspirującym duchowo, przestrzenią zdolną wskrzesić kaszubskiego ducha, autor uczynił inny obszar kultu religijnego. Mit żywy umiejscowił pisarz tam, gdzie lud kaszubski zbiera się thumnie na co dzień i z okazji wielkich religijnych uroczystości - na Kalwarii Wejherowskiej.

Kalwaria Wejherowska to perła w koronie Kaszub (ryc. 6). Przypisuje się temu miejscu funkcję mityczną i mitotwórczą. „Nasze swianté górë” - jak nazywa się tę kalwarię w mowie kaszubskich Ojców - to wyjątkowy obszar w topografii Kaszub. Na kaszubską Jerozolimę można bowiem spoglądać nie tylko z perspektywy regionalnej, lecz również jak na dzieło Rzeczpospolitej i dziedzictwo epoki baroku. Ufundowana przez Jakuba Wejhera, jego rodzinę i przyjaciół jako wotum za cudowne ocalenie od śmierci w bitwie pod Smoleńskiem, trwa po dziś dzień i trwać będzie w przyszłości jako duchowa stolica Kaszub. Wyznacznikiem fenomenu kaszubskiej Jerozolimy jest jej znaczenie w tradycji i kulturowej tożsamości Kaszub i Pomorza (Krawiec-Złotkowska 2008, s. 7). 
Mityczna Kalwaria Wejherowska występuje już w młodzieńczym utworze Aleksandra Majkowskiego pt. Pielgrzymka wejherowska ${ }^{14}$, w którym kaszubską Jerozolimę autor uczynił poniekąd głównym „bohaterem” dzieła. Tadeusz Linkner podkreśla, że młodopolski pisarz nie zapomniał wygłosić hymnicznej pochwały tego miejsca, do którego od wieków zdążały pielgrzymki i które zasłużyło na swoje miano. Majkowski wprowadził do narracji laudację ,świętych gór”, bo były one dla Kaszubów (i są nadal) miejscem chrześcijańskiego sacrum. Mieszkańcom kaszubskiej ziemi Majkowski dał również nadzieję na rychłe uwolnienie się spod pruskiego zaborcy, bo właśnie w tej intencji modlono się wówczas na wejherowskiej kalwarii najczęściej, głęboko wierząc w sakralną moc tego miejsca, uniwersalnie niezłomnego i bezpiecznego $\mathrm{z}$ racji mitycznej potęgi słowiańskiego dębu i skały - opoki wiary (Linkner 2008, s. 81).

Mityczną rangę kaszubskiej ziemi przedstawionej w Pielgrzymce wejherowskiej potwierdzają słowa:

Póki ty, o góro, sterczysz swoją skałą

I nad twą świątynią krzyż świeci wspaniało,

Póki ty rej wodzisz między pagórkami

Z koronami kaplic, z stróżami dębami,

Póty wiara ojców u nas nie zaginie (s. 15).

Dąb i skała - ze względu na ich symbolikę - stanowią niekwestionowany fundament trwania. Należy pamiętać, że młodopolski autor pisał Pielgrzymkę... w szczególnie trudnym i ciężkim okresie - w jarzmie pruskiej niewoli. Tym samym nie o latwe trwanie mu chodziło, lecz o przetrwanie i odrodzenie. Prawdopodobnie ze względu na czas historyczny, laudację Kaszubskiej Jerozolimy zakończył Majkowski patriotycznym kazaniem ,pasterza”:

Głoszą pisma, że z woli Bożej przed końcem świata

Antychryst panować będzie ziemi długie lata

I wytrwałych w wierze ściskać ostremi karami.

Nie czekajcie, Antychrysty są już między wami.

Chcą nam wydrzeć mowę naszą, pamięć ojców naszych,

Role, cośmy w spadku wzięli, po praojcach naszych,

Rzucają się na nas, diabłów udawając chmarę,

Na zgrzybiałe Boże męki i na naszą wiarę,

Na kościoły i kaplice święte w cieniu lasów,

Których wiek dosięga dawnych ojców naszych czasów (s. 15-16).

Antychryst z Pielgrzymki wejherowskiej - to bez wątpienia figura ciemiężcy Niemca, którego z racji cenzury nie mógł Majkowski w swym utworze nazwać

\footnotetext{
${ }^{14}$ Cytaty z Pielgrzymki wejherowskiej według edycji: A. Majkowski 1992.
} 
wprost. W eposie Życie i przygody Remusa najeźdźca objawił się w postaci złego ducha plączącego losy kaszubskiego ludu - Smętka. To on w mitycznym wymiarze jest odpowiedzialny za tragedię gnębionych przez zaborcę Kaszubów, którzy ratunku szukali właśnie na wejherowskiej kalwarii. Pielgrzymi odwiedzali to miejsce kultu, by na „świętych górach”, jednocząc się z męką Chrystusa i cierpieniem Jego Matki, zostawić swe troski i żale. W Pielgrzymce wejherowskiej do ich modlitwy i skargi zdawała się włączać cała natura:

Straszna, wielka i płacząca skarga tam zabrzmiała, Dąb dębowi, góra górze dalej podawała (s. 16).

Konwencja baśni, którą dostrzegamy w przywołanym cytacie, bliska jest obrazowaniu modernistycznemu, a zarazem dotyka sfery mitu. Właśnie takie mityczne postrzeganie i rozumienie świata tytułowemu bohaterowi drugiego dzieła Majkowskiego, Remusowi, dało możliwość ujrzenia całych Kaszub, które szły na kalwarię pod znakiem krzyża:

Spojrzałem na las chorągwi i na morze ludu kaszubskiego, który się tłoczył na szerokim gościńcu prowadzącym z Gdańska na niemieckie Pomorze. $Z$ wysoka, z postrzępionych chmur, patrzyły na nich kaplice kalwarii. Był to lud prosty: tędzy gospodarze, rośli rybacy, hoże młode kobiety i stare babiny. Gdyby za nimi stanęli ci, co z Garecznicy wyszli za kompanią, i ci, których widziałem w Mirachowskim Lesie w piórzastych hełmach na wysokich koniach, byłby to naród peten chwały!

[...] tę pierwszą pielgrzymkę zapisała pamięć w mym sercu największymi literami. Bo co na nauce dziecku opowiadał dobry ksiądz, tu stanęło mi na jawie przed oczyma. Tak jakby od tamtych dziejów litościwego Boga na ziemi nie upłynęły do wieczności prawie dwa tysiące lat. $Z$ góry $w$ dół i z dołu w górę ciężka wiodła droga [...]. Kurz jak mgła płynął nad pobożnym ludem, ale mnie się zdawało, że chodzę w porannej mgle młodego dnia wiary naszej. Jak kamienni świadkowie na świętej ziemi stały kaplice wśród starodawnych buków na wzgórzach i otwierały swe bramy i zapraszały: Chodźcie dzieci Wiary! (s. 166-168).

Nauki, które przekazał Remusowi ksiądz Paweł, wytyczyły religijną drogę bohatera oraz ukształtowały jego system aksjologiczny. Wiara żywa, nierozerwalnie związana z kultem - zwłaszcza praktykami pątniczymi - była tym, co Remus nie tylko przeżywał, ale co stanowiło dla niego źródło inspiracji. Ksiądz-nauczyciel jawi się w tym kontekście jako moralny i ideowy mentor. Być może dzięki jego naukom (oraz lekcjom dawanym przez pana Józefa) bohater widzi „,wojsko duchów" w Mirachowskim Lesie i ma wizje z chwalebnej przeszłości Kaszubów, żadną miarą nieprzystające do ich wizerunku z końca XIX w. 


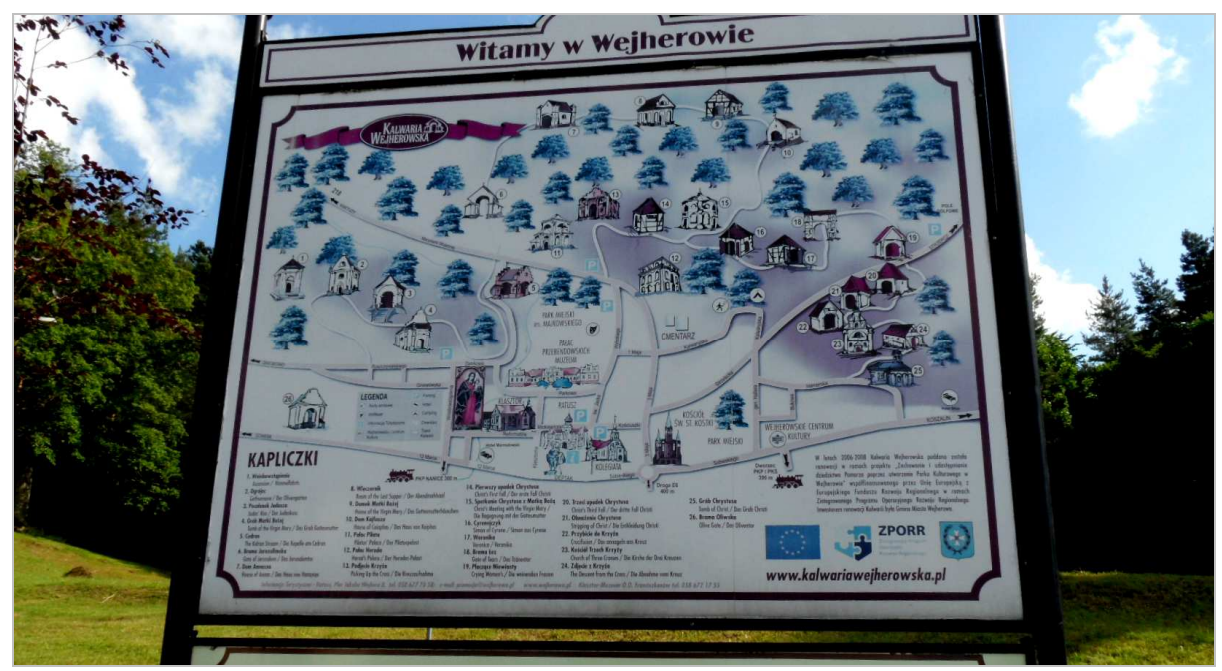

Ryc. 6. Plan Kalwarii Wejherowskiej Źródło: fot. K. Krawiec-Złotkowska

Symboliczny charakter w Życiu i przygodach Remusa ma pożar ostatniego kościoła „na Pomorsce”. Bohater jest świadkiem tego zdarzenia i odczytuje je jako znak Boży. Jednak już wcześniej, gdy ze swoim wiernym druhem Trąbą stanął „w smołdzińskim kościele”, Remus snuje refleksje niezwykle istotne w kontekście interesujących autorkę niniejszego artykułu zagadnień:

Długo stałem i patrzyłem na obraz wielkiego Mostnika, który tu zakładał swój kościół słowiński. Lecz jego doniosłe zamierzenie nie mogło tu zapuścić trwałych korzeni, bo nie dostawało mu opieki naszego świętego kościoła powszechnego.

Wysoko ponad kościół wznosi się, jakby usypana przez stolemów, pamię tna góra Rewekol. [...] Niebo spoglądało słonecznym okiem, jakby radowało się tym pięknym krajem. A dusza moja płakała, jak na cmentarzu moich braci (s. 288-289).

Interpretacja Remusowa, dotycząca przyczyn upadku „słowińskiego kościoła", nie pozostawia złudzeń. Zdaniem bohatera odłączony od Kościoła powszechnego, czyli rzymskiego i w tym kontekście na pewno katolickiego z obrządkiem łacińskim, nie miał szansy na przetrwanie. Tym samym nadzieję na odrodzenie Kaszubów i uratowanie ich mowy pokłada bohater w Kościele katolickim. Artykułuje to w pełni właśnie wówczas, gdy opowiada o płonącej świątyni główczyckiej: 
Oczy moje prowadziły mnie na ten kościół, z którego dopiero co wypędzono naszą mowę. [...] I łatwo było rozpoznać, gdzie się chował nasz świat kaszubski, a gdzie do ziemi się kładli dzisiejsi potomkowie. Bo w starej kaszubskiej połowie cmentarza kwitły kwiatki takie same jak u nas na wsi przed oknami chat. Z lasu kwiatków wznosiły się krzyże o dziwnych kształtach, wykute z żelaza, i tablice wyciosane z drzewa i malowane takimi barwami, jakimi Pan Bóg przystroił swojskie kwiatki na grobach. W nowej połowie cmentarza stały czarne krzyże z niemieckimi napisami, ustawione w rzędy jak wojsko; tu już było obco.

Bliżej kościoła, patrzącego na ten niemiecki porządek jak kokoszka, która cudze pisklęta wysiedziała, pyszniły się grobowe kaplice wielkich i możnych rodów kaszubskich. Od nadchodzącej burzy zrobiło się tak ciemno, że tylko z dużym trudem mogłem przeczytać ich nazwiska. Chociaż poprzekręcane były na niemiecką modłę, odczytałem przecież nazwiska kaszubskiego rycerstwa: Będzemirów, Domarusów, Borków, Żyżewiczów, Wilków, Stojentinów, Rekowów, Zastrowców, Nadzmirów i innych. [...] nagle cały cmentarz stanął w ogniu i straszny huk wstrząsnął ziemią i kaplicą i wyrzuciło nas w górę, i uderzyło o ziemię. Podnosząc się zobaczyliśmy, że kościół pali się jak wielka pochodnia.

To uderzył piorun boży i spalił świątynię, w której zduszono mowę tych, co ją zbudowali na jego chwałę (s. 291-292).

\section{Wnioski}

Pamiętając, jak ważna jest wiara dla Kaszubów, i opierając się na opiniach oraz „,argumentach”, jakich dostarcza literatura piękna, można konstatować, że konfesja katolicka odgrywała ogromną rolę w kształtowaniu tożsamości kaszubskiego ludu i pielęgnowania przez Kaszubów na równych prawach polskich i kaszubskich tradycji i języka.

Kościół katolicki, przedstawiany w kaszubskiej literaturze pięknej, jawi się jako ostoja dla rodzimej kultury i jednocześnie dla polskości, z którą Kaszubi się identyfikowali. Do określenia ich wyjątkowej tożsamości łączącej kaszubskość z polskością przyczynił się H. Derdowski. Z kolei A. Majkowski, będąc piewcą kaszubskiej kultury i postulując ochronę kaszubskiego języka, jest jednocześnie twórcą, który otwarcie mówi, że tam, gdzie zapanowała niemczyzna (a Kościoły protestanckie bez wątpienia w działalność antypolską i antykaszubską były zaangażowane), umarła mowa kaszubskich protoplastów. Dodatkowo język i wyznania protestanckie wywoływały negatywne skojarzenia, ponieważ Niemcy byli zaborcami. Pozytywnie wartościowano ,wiarę i język ojców”, które na Kaszubach utożsamiano z językiem i kulturą polską. Kultywowanie tradycji katolickiej i pielęgnowanie religijnych rytuałów umożliwiał i wspierał literacki dialog polsko-kaszubski. 
Interpretacja dzieł kaszubskich ujawnia mityczne myślenie o miejscu życia i takież - w kategoriach mitycznych - rozumienie i pojmowanie przestrzeni; religia i konfesja stają się potwierdzeniem tożsamości człowieka, identyfikują go z określoną nacją i kulturą. Literatura ma charakter mimetyczny, czyli odzwierciedla rzeczywistość - a skoro tak, to można ją traktować jako źródło paradokumentalne, a na pewno świadectwo czasów i zjawisk z przeszłości. Trzeba również pamiętać, że poza dokumentami jest człowiek, który żyje w określonych uwarunkowaniach egzystencjalnych i sam dokonuje wyborów - Kaszubi wybrali polskość, a obrzędy religijne sprawowane w Kościele katolickim ten wybór i utrzymanie polskości konstytuują.

\section{Literatura}

Borzyszkowski J., 2011, O historii literatury kaszubskiej i jej twórcach, Gdańsk.

Borzyszkowski J., Mordawski J., Treder J., 1999, Historia, geografia i piśmiennictwo Kaszubów, Gdańsk.

Bukowski A., 1950, Regionalizm kaszubski. Ruch naukowy, literacki i kulturalny. Zarys monografii historycznej, Poznań.

Kalinowski D., 2009, Spiskowiec, folklorysta i samotnik - Florian Ceynowa a romantyzm, [w:] Kuik-Kalinowska A., Kalinowski D., Od Smętka do Stolema. Wokół literatury Kaszub, Gdańsk-Słupsk.

Karnowski J., 1997, Dr Florian Ceynowa, oprac. i posł. J. Treder, Gdańsk.

Klemp A., 1994, Protestanci $w$ dobrach prywatnych $w$ Prusach Królewskich od drugiej połowy XVII do drugiej połowy XVIII wieku, Gdańsk.

Krawiec-Złotkowska K., 2008, Wstęp, [w:] Krawiec-Złotkowska K. (red.), Kalwaria wejherowska. Żywy pomnik kultury barokowej na Pomorzu, Wejherowo, s. 7-11.

Krawiec-Złotkowska K., 2012, Mityczna wizja kościoła $w$ wielkiej literaturze kaszubskiej, [w:] Krawiec-Złotkowska K. (red.), Rzeczpospolita domów III. Domy Boże, Słupsk, s. $108-128$.

Krawiec-Złotkowska K., 2017a, Opinie uczonych Lwowa, Krakowa, Torunia (?) $i$ Warszawy o poemacie Hieronima Derdowskiego kamieniem wegielnym $w$ emancypacji literatury kaszubskiej, [w:] Chojnowski Z., Rybicka E. (red.), Regionalizm literacki-historia i pamięć, Kraków, s. 538-559.

Krawiec-Złotkowska K., 2017b, The reception of the first literary texts edited in Kashubian language in the context of the so-called „Kashubian issue”, [w:] Heffner K., Solga B. (red.), Borderlands of Nations, Nations of Borderlands. National, ethnic and religious minorities in the Polish space - selected issues. Region and Regionalism, $\mathrm{nr} 13$, t. 2, Łódź-Opole, s. 91-109.

Kroczyński H., 1979, Kołobrzeg - zarys dziejów, Poznań. 
Labuda G., 1996, Kaszubi i ich dzieje, Gdańsk.

Labuda G., 2000, Kaszubi i ich dzieje. Pisma wybrane, Gdańsk.

Linkner T., 2008, Aleksandra Majkowskiego „Pielgrzymka Wejherowska” z końca wieku XIX, [w:] Krawiec-Złotkowska K. (red.), Kalwaria Wejherowska. Żywy pomnik kultury barokowej na Pomorzu, Wejherowo.

Mordawski J., 1999, Geografia współczesnych Kaszub, Gdańsk.

Piskorski J.M., 2002, Pomorze plemienne. Historia - archeologia-językoznawstwo, Poznań.

Ramułt S., 1893, Wstęp. Kilka słów o Kaszubach i ich mowie, [w:] Ramułt S. (red.), Słownik języka pomorskiego, czyli kaszubskiego, Kraków.

Samp J., 2007, Oblicza pisarstwa poety z Wiela, [w:] Derdowski H.J., Ó panu Czôrlińsczim, co do Pùcka pò sécë jachôt, oprac. J. Samp, J. Treder, E. Gołąbek, Gdańsk.

Słomczyński T., 2016, Skąd się wzięli Kaszubi? Rozmowa z prof. Cezarym Obrachtem-Prondzyńskim, „Magazyn Kaszuby”, 30 III, wydanie elektroniczne.

Szultka Z., 1991, Język polski w Kościele ewangelicko-augsburskim na Pomorzu Zachodnim od XVI do XIX wieku, Wrocław.

Szultka Z., 1994, Piśmiennictwo polskie i kaszubskie Pomorza Zachodniego od XVI do XIX wieku, Poznań.

Treder J., 2005, Historia kaszubszczyzny literackiej. Studia, Gdańsk.

Ustawa z dnia 6 stycznia 2005 r. o mniejszościach narodowych i etnicznych oraz o języku regionalnym, DzU 2005, $\mathrm{nr}$ 17, poz. 141.

\section{Źródła}

Derdowski H., 1880, O panu Czorlińscim co do Pucka po sece jachol, zełgot dlo swojech druchow kaszubściech Jarosz Derdowski, Torun.

Derdowski H., 1939, Pisma proza, oprac. A. Bukowski, Kartuzy.

Gliński H. (red.), 1882, „Gwiazda”. Kalendarz petersburski, premiowy, ilustrowany, literacki, spoleczny i informacyjny, na rok zwyczajny 1882, Petersburg.

Majkowski A., 1966, Życie i przygody Remusa, z gwary kaszubskiej przeł. L. Bądkowski, Gdynia.

Majkowski A., 1973, Pomorzanie, z rękopisu do druku przygotowała i wstępem opatrzyła D. Majkowska, Gdańsk.

Majkowski A., 1992, Pielgrzymka Wejherowska, poemat podał do druku i posłowiem opatrzył E. Puzdrowski, Gdynia.

\section{Źródła internetowe}

Gburczyk J., Historia Łeby. Kościół i reformacja: https://historialeby.pl.tl/Ko\%26\%23347 \%3Bci\%F3\%26\%23322\%3B-i-reformacja.htm (18.11.2017). 
http://odwiedzkaszuby.pl/granice-kaszub-na-przestrzeni-wiekow/ (18.11.2017).

http://magazynkaszuby.pl/2016/03/skad-sie-wzieli-kaszubi-cezary-obracht-prondzynski/ (18.11.2017).

Ludność wedlug narodowości, płci oraz miejsca zamieszkania w 2002 r., Główny Urząd Statystyczny, https://stat.gov.pl/spisy-powszechne/narodowe-spisy-powszechne/narodo wy-spis-powszechny-2002/wyniki-narodowego-spisu-powszechnego-2002-narodowos ci-oraz -jezyka/ (18.11.2017).

\title{
The role of Catholic confession in preserving Polishness in Kashubia at the turn of the $19^{\text {th }}$ and $20^{\text {th }}$ centuries
}

\begin{abstract}
Summary
The study discusses issues concerning the historical boundaries of Kashubia and the relations of their inhabitants with the Catholic church. The author attempted to determine whether the confession had an impact on the preservation of Polishness in this specific area. For Kashubians are a region of Poland in which the Kashubian and Polish traditions (including religious ones) are cultivated as equivalent. Based on historical and linguistic studies as well as selected literary texts, it can be assumed that the Kashubian people, thanks to belonging to the Catholic church, did not get Germanized, as was the case in the Pomeranian region, dominated in the nineteenth century by Protestantism.
\end{abstract}

Keywords: history and borders of Kashubia, Western Pomerania, Eastern Pomerania, Kashubian language, Catholic church, kulturkampf, Florian Ceynowa, Hieronim Derdowski, Aleksander Majkowski, Polishness in Kashubia.

Dr hab. Krystyna Krawiec-Złotkowska, prof. AP

Akademia Pomorska w Słupsku

Instytut Polonistyki

ul. Arciszewskiego 22a, Słupsk 76-200

e-mail: krystyna.krawiec-zlotkowska@apsl.edu.pl 